DOI: https://doi.org/10.36910/6775-2524-0560-2021-42-07

UDC 517.958:52/59

Hubal Halyna M., Ph.D. (Physical and Mathematical Sciences), Associate Professor, Lutsk National Technical University, Lutsk, Ukraine

\title{
MATHEMATICAL MODELING OF BIOCHEMICAL PROCESSES RATES IN BIOLOGICAL SYSTEMS
}

Губаль Г.М. Математичне моделювання швидкостей біохімічних процесів в біологічних системах. У статті виконано математичне моделювання швидкостей біохімічних процесів в біологічних системах. Розглянуто і досліджено приклад ферментативних реакцій.

Ключові слова: біохімічний процес, ферментативна реакція, система диференціальних рівнянь.

Губаль Г.Н. Математическое моделирование скоростей биохимических процессов в биологических системах. В статье выполнено математическое моделирование скоростей биохимических процессов в биологических системах. Рассмотрено и исследовано пример ферментативных реакций.

Ключевые слова: биохимический процесс, ферментативная реакция, система дифференциальных уравнений.

Hubal H.M. Mathematical modeling of biochemical processes rates in biological systems. Mathematical modeling of biochemical processes rates in biological systems is performed in the article. An example of enzymatic reactions is considered and investigated.

Keywords: biochemical process, enzymatic reaction, system of differential equations.

Formulation of the scientific problem. The processes that take place in living cells consist of a large number of reactions catalyzed by various enzymes [1]-[3]. For mathematical modeling of these biochemical processes in biological systems, it is necessary to construct systems of a large number of nonlinear differential equations with the same large number of variables [4]-[6]. Even mathematical modeling of individual chains of biochemical processes that consist of a large number of enzymatic reactions is quite complex.

Research analysis. To solve these problems, it is necessary to make simplifications taking into account some features of these reactions.

In the chain of reactions that take place in a living cell, the slowest reaction is determining. The slowest reaction is determined by the lowest value of the velocities. In the chain of enzymatic reactions, the reaction with the lowest maximum rate will be decisive (see the example of a chain of two consecutive enzymatic reactions given below). When diffusing through several partitions, the determining link will be the partition with the lowest diffusion coefficient. By the reaction rate, we mean the maximum rate of that reaction.

Presentation of the main material and the justification of the obtained research results. To find the determining link in the chain of biochemical reactions, it is necessary to find out how the rate of the whole process, i.e. the rate of production of the last link, depends on the rates of individual reactions. Obviously, when changing the maximum rates, any changes in the fast links will not affect the rate of the whole process. The rate of the whole process is affected only by the slowest link.

When the rates of individual reactions in the chain of biochemical reactions differ by orders of magnitude, i.e. by $10 ; 100$ or more times, all fast reactions have time to reach equilibrium during the slowest reaction.

Since enzymatic reactions have the properties of low inversion and saturation, even when the rates of individual reactions differ little, the rate of the whole process depends only on the rate of the slowest link. Therefore, changes in other faster reactions have almost no effect on the overall rate.

Let us prove this using the example of a chain of two consecutive enzymatic reactions:

$$
\begin{gathered}
S+F_{1} \underset{k_{-1(1)}}{\stackrel{k_{+1(1)}}{\rightleftarrows}}\left[F_{1} S\right] \stackrel{k_{+2(1)}}{\stackrel{k_{-2(1)}}{\longrightarrow}} P_{1}+F_{1} ; \\
P_{1}+F_{2} \underset{k_{-1(2)}}{\stackrel{k_{+1(2)}}{\rightleftarrows}}\left[F_{2} P_{1}\right] \stackrel{k_{+2(2)}}{\longrightarrow} P_{2}+F_{2},
\end{gathered}
$$


where

- the substrate $S$, combining with the enzyme $F_{1}$ (in the first reaction), forms the complex $\left[F_{1} S\right]$, and the final reaction product $P_{1}$ is the substrate (the initial product) of the second reaction;

- $\quad S$ is the substrate of the first reaction;

- $\quad F_{1}, F_{2}$ are enzymes;

- $\quad k_{+2(1)}$ is the absolute rate of decay of the complex $\left[F_{1} S\right]$ into the product $P_{1}$ and the enzyme $F_{1}$;

- $\quad k_{-2(1)}$ is the absolute reaction rate of the synthesis of the complex $\left[F_{1} S\right]$;

- (1), (2) are indices that indicate, respectively, the first, second reaction. In the reaction

$$
\left[F_{1} S\right] \underset{k_{-2(1)}}{\stackrel{k_{+2(1)}}{\leftrightarrows}} P_{1}+F_{1}
$$

a short arrow in the opposite direction indicates that the reaction is slightly reversed.

Note that the reaction rate primarily depends on the probability of collision, for example, in the first reaction of the substrate molecules $S$ with the enzyme molecules $F_{\mathrm{I}}$. The probability of encountering these molecules is proportional to the product of concentrations $c_{S}$ and $c_{F_{1}}$. Then the reaction rate of their synthesis during the interaction is

$$
v_{\left[F_{1} S\right]}=k_{+1(1)} c_{F_{1}} c_{S}
$$

where

- $k_{+1(1)}$ is the absolute reaction rate of the synthesis of the complex $\left[F_{1} S\right]$, which takes into account the average collision efficiency, depends on the temperature (which determines the rate of molecules) and other factors;

- $\quad c_{F_{1}}$ is the concentration of the enzyme $F_{1}$ (the concentration of the free enzyme $F_{1}$ );

- $\quad c_{S}$ is the concentration of the substrate $S$.

By the effectiveness of the collision, we mean the formation, in this case, of a new complex molecule of the complex of two molecules $\left[F_{1} S\right]$ at the meeting (collision) of the molecule of the substrate $S$ with the molecule of the enzyme $F_{1}$.

Similarly, the rate of decay of the complex $\left[F_{1} S\right]$ is

$$
v_{\left[F_{1} S\right] \rightarrow F_{1}+S}=k_{-1(1)} c_{\left[F_{1} S\right]},
$$

where

- $\quad k_{-1(1)}$ is the absolute rate of decay of the complex $\left[F_{1} S\right]$ into the substrate $S$ and the enzyme $F_{1}$;

- $c_{\left[F_{1} S\right]}$ is the concentration of the complex $\left[F_{1} S\right]$ (the concentration of the bound enzyme $F_{1}$ ).

Other rates of these two successive enzymatic reactions are similarly determined.

If the maximum rate of the second reaction is greater than the maximum rate of the first one, then the rate of the process is determined by the first reaction. So, everything that is produced in the first reaction, goes on without delay.

If, for example, the action of any inhibitors changes the rate of the second reaction, then taking into account the irreversibility of the second reaction, the rate of the first reaction will not change if the rate of the second reaction remains at least slightly higher than the first one. In this case, the rate of this whole process can only be affected by inhibitors of the first reaction. Thus, in this case, the inhibitors of the first reaction can control the rate of the whole process.

However, if the maximum rate of the second reaction is less than the first one, the intermediate product will accumulate. If we do not take into account at least the weak inversion of the first reaction or any 
other ways of outflow of the product, the accumulation will continue indefinitely and a steady flow of the process is impossible.

Thus, in this case, the reversal (at least weak) plays an important role and must be taken into account.

Thus, the concentration of the intermediate product will grow until its reverse flow is equal to the difference between the inflow due to the first reaction and the outflow due to the second one. Therefore, a large amount of this product will accumulate, i.e. its reserve.

In this case, the rate of the second reaction as a determining one due to saturation will not depend on the concentration of the intermediate product and, therefore, on the values that affect the rate of the first reaction. This will be as long as the rate of the first reaction is greater than the rate of the second reaction.

Thus, the inhibitor does not affect the rate of the whole process as long as the rate of reaction it affects is not the lowest. However, when a certain concentration of the inhibitor is reached, when the rate of the reaction it affects becomes less than the rate of other reactions, then a further increase in the concentration of this inhibitor reduces the rate of the whole process. Then other inhibitors cease to act on the rate of the whole process.

This course of biochemical processes in biological systems simplifies the research.

The problem of regulation and self-regulation is one of the most important for cells. The principle of the lowest rate facilitates regulation, allows, in stationary conditions, to watch separate especially important reactions despite others.

If this principle of the lowest rate did not work, the cell would need to monitor a large number of different reactions simultaneously.

Obviously, the evolution of biological systems led to the selection of the connections between processes that simplified and made more reliable the system of self-regulation.

The accumulation of the product reserve before the next link (as described above) ensures the independent operation of this next link, making it quite autonomous and independent of other links of the process. This principle of autonomy of individual links is also very important for self-regulating systems.

The presence of a product reserve leads to greater inertia of the system. When, under the action of inhibitors, the accumulation of the product reserve occurs before another link, it switches to the second mode. The larger the reserve, the slower this switch is.

To consider transient modes, it is necessary to consider nonstationary solutions of kinetic equations.

The study of biological systems over time is quite complex. Even in simple biochemical processes in biological systems, dozens of intermediate products interact. Therefore, mathematical models of these processes contain dozens of equations.

To simplify mathematical models, it is necessary to reduce the number of variables and equations. To do this, we can use the fact that the rates of individual reactions in biochemical processes are quite different. There are mostly normal, fast, very fast, slow and very slow reactions. For example, if we are interested in changes in the system that take place in a few minutes, then the processes that take place in seconds and split seconds are considered fast and very fast, and the processes that take place in hours and days are considered slow and very slow.

If we are interested in changes by seconds, then processes by minutes are considered to be slow.

Thus, we can divide reactions into such groups: a) and b). Note the following:

a) All concentrations that change slowly and very slowly can be considered to be constant and equal to the initial value. Then in the equations the corresponding variables become parameters and the number of equations decreases.

b) In fast and very fast reactions, stationary concentrations are established. Then the differential equations describing these reactions are replaced by algebraic equations and the system of differential equations is further simplified. remain.

After these simplifications a) and b) only reactions proceeding at approximately the same rates will

Consider the following example.

Suppose that among $N$ components of the biochemical process, there is a component with the concentration $c_{1}$, that is formed very quickly (i.e. the rate $\frac{d c_{1}}{d t}$ is very high), but is also consumed very quickly. Otherwise, it would accumulate quickly. Then taking into account that the rate $\frac{d c_{1}}{d t}$ is very high, for this component, the differential equation can be written in the form: 


$$
\frac{d c_{1}}{d t}=M f_{1}\left(c_{1}, c_{2}, c_{3}, \ldots, c_{N}\right)
$$

or

$$
m \frac{d c_{1}}{d t}=f_{1}\left(c_{1}, c_{2}, c_{3}, \ldots, c_{N}\right)
$$

where

$$
m=\frac{1}{M}
$$

$M$ is a very large number, i.e. $M$ is much greater than one $(M \gg 1)$ and, therefore, $0<m \ll 1$, and $f_{1}\left(c_{1}, c_{2}, c_{3}, \ldots, c_{N}\right)$ is a normal rate in magnitude.

From differential equation (2), it is obvious that the rate $\frac{d c_{1}}{d t}$ is very high, and the rate $f_{1}\left(c_{1}, c_{2}, c_{3}, \ldots, c_{N}\right)$ is a normal in magnitude.

Then according to $b$ ) given above, differential equation (2) can be replaced by the algebraic equation that connects stationary concentrations:

$$
f_{1}\left(\bar{c}_{1}, \bar{c}_{2}, \bar{c}_{3}, \ldots, \bar{c}_{N}\right)=0
$$

Note that, when replacing formula (2) by formula (3), it is taken into account that $\frac{d \bar{c}_{1}}{d t}=0$ since the stationary concentration $\bar{c}_{1}$ is a constant value.

From equation (3), we express $\bar{c}_{1}$ through other variables. Thus, we reduce the number of differential equations.

Let the concentration $c_{1}$, at the initial moment of time $t_{0}$, differ from its stationary value $\overline{c_{1}}$ by a small value $\Delta c_{1}$. Then

$$
c_{1}=\bar{c}_{1}+\Delta c_{1}
$$

All other concentrations should be stationary, i.e. $\bar{c}_{2}, \bar{c}_{3}, \ldots, \bar{c}_{N}$, at $t=t_{0}$.

Then the function $f_{1}$, at the moment of time $t_{0}$, can be written in the form:

$$
f_{1}=f_{1}\left(\bar{c}_{1}+\Delta c_{1}, \bar{c}_{2}, \bar{c}_{3}, \ldots, \bar{c}_{N}\right)
$$

Let us decompose function (4) into a Taylor series on $\Delta c_{1}$ about the point $\bar{c}_{1}$. Taking into account the smallness $\Delta c_{1}$, we will limit ourselves to the first term of the series. Then taking into account formula (3), we obtain:

$$
f_{1}\left(\bar{c}_{1}+\Delta c_{1}, \bar{c}_{2}, \bar{c}_{3}, \ldots, \bar{c}_{N}\right) \approx f_{1}\left(\bar{c}_{1}, \bar{c}_{2}, \bar{c}_{3}, \ldots, \bar{c}_{N}\right)+\left.\frac{\partial f_{1}}{\partial c_{1}}\right|_{c_{1}=\bar{c}_{1}} \Delta c_{1}=0+\lambda \Delta c_{1}=\lambda \Delta c_{1},
$$

where $\lambda=\left.\frac{\partial f_{1}}{\partial c_{1}}\right|_{c_{1}=\bar{c}_{1}}$ 
Note that the partial derivative $\frac{\partial f_{1}}{\partial c_{1}}$ of the function $f_{1}\left(c_{1}, c_{2}, c_{3}, \ldots, c_{N}\right)$ with respect to $c_{1}$ at the point $c_{1}=\bar{c}_{1}$ is taken at $c_{2}=\bar{c}_{2}, c_{3}=\bar{c}_{3}, \ldots, c_{N}=\bar{c}_{N}$.

Substituting

$$
c_{1}=\bar{c}_{1}+\Delta c_{1} \quad \text { i } f_{1}\left(c_{1}, c_{2}, c_{3}, \ldots, c_{N}\right)=f_{1}\left(\bar{c}_{1}+\Delta c_{1}, \bar{c}_{2}, \bar{c}_{3}, \ldots, \bar{c}_{N}\right)
$$

into differential equation (1), we obtain:

$$
\frac{d}{d t}\left(\bar{c}_{1}+\Delta c_{1}\right)=M f_{1}\left(\bar{c}_{1}+\Delta c_{1}, \bar{c}_{2}, \bar{c}_{3}, \ldots, \bar{c}_{N}\right)
$$

Then taking into account that $\bar{c}_{1}$ is constant, and $\Delta c_{1}$ is variable, i.e. $\Delta c_{1}=\Delta c_{1}(t)$, and formula (5), we obtain:

$$
\frac{d}{d t} \Delta c_{1}(t)=M \lambda \Delta c_{1}(t)
$$

Note that for simplification in formula $(6)$, we put the sign $=$ instead of the sign $\approx$.

Let us write differential equation (6) in the following form:

$$
\frac{d\left(\Delta c_{1}(t)\right)}{\Delta c_{1}(t)}=M \lambda d t
$$

Then

$$
\int_{\Delta c_{1}\left(t_{0}\right)}^{\Delta c_{1}(t)} \frac{d\left(\Delta c_{1}(t)\right)}{\Delta c_{1}(t)}=\int_{t_{0}}^{t} M \lambda d t,
$$

whence at $\Delta c_{1}(t)>0$ (and therefore, $\Delta c_{1}\left(t_{0}\right)>0$ ), taking into account that $M$ and $\lambda$ do not depend on $t$, we get:

$$
\left.\ln \left(\Delta c_{1}(t)\right)\right|_{\Delta c_{1}\left(t_{0}\right)} ^{\Delta c_{1}(t)}=\left.M \lambda t\right|_{t_{0}} ^{t}
$$

or

$$
\ln \left(\Delta c_{1}(t)\right)-\ln \left(\Delta c_{1}\left(t_{0}\right)\right)=M \lambda\left(t-t_{0}\right)
$$

or

$$
\ln \frac{\Delta c_{1}(t)}{\Delta c_{1}\left(t_{0}\right)}=M \lambda\left(t-t_{0}\right)
$$

Hence, we obtain the solution of differential equation (6):

$$
\frac{\Delta c_{1}(t)}{\Delta c_{1}\left(t_{0}\right)}=e^{M \lambda\left(t-t_{0}\right)}
$$

or

$$
\Delta c_{1}(t)=\left(\Delta c_{1}\left(t_{0}\right)\right) e^{M \lambda\left(t-t_{0}\right)} .
$$


If a steady state corresponding to equation (3) is stable, then over time ( $t$ increases) $\Delta c_{1}(t)$ decreases. Then (at the stable steady state) solution (7) of differential equation (6) takes on the form:

$$
\Delta c_{1}(t)=\left(\Delta c_{1}\left(t_{0}\right)\right) e^{-M|\lambda|\left(t-t_{0}\right)} .
$$

Thus, according to formula (8), establishment of the stable steady state corresponding to equation (3), occurs because as $|\lambda| \rightarrow \infty$, the value $\Delta c_{1}(t) \rightarrow 0$.

The presence in formula ( 8 ) of a very large factor $M$ in the exponent provides a very fast approach to zero $\Delta c_{1}(t)$ (i.e. $\Delta c_{1}(t) \rightarrow 0$ ) and, therefore, very fast establishment of stationary value of the concentration $\bar{c}_{1}$ (i.e. $\left.c_{1}(t) \rightarrow \bar{c}_{1}\right)$ since $c_{1}(t)=\bar{c}_{1}+\Delta c_{1}(t)$.

In biochemical processes, the rates of individual reactions are significantly different.

The fastest reactions in living cells are enzymatic.

The rate of the enzymatic reaction is characterized by the time of the enzymatic reaction $\tau_{F}$ that depends on the number of revolutions of the saturated enzyme:

$$
\tau_{F} \approx \frac{c_{S}}{c_{F_{0(1)}}} \cdot \frac{1}{k_{+2(1)}},
$$

where

$$
c_{F_{0(1)}}=c_{F_{1}}+c_{\left[F_{1} S\right]}
$$

$c_{F_{0(1)}}$ is the initial concentration of the enzyme $F_{1} ; c_{F_{0(1)}}=$ const;

$c_{F_{1}}$ is the concentration of the free enzyme $F_{1}$;

$c_{\left[F_{1} S\right]}$ is the concentration of the bound enzyme $F_{1}$ (the concentration of the complex $\left[F_{1} S\right]$ ).

The values $\tau_{F}$ in different enzymes are quite different. They are from hundredths of a second to minutes. Such a large difference between the rates makes it possible to distinguish fast and very fast reactions in comparison with normal ones in the chain of enzymatic reactions. Then the rate of the chain of reactions is determined by the slowest reactions. These times can be even a little longer due to the accumulation of reserve.

The next step is the synthesis of macromolecules. These processes require much more time. The attachment of only one amino acid to the protein chain or one nucleotide to the RNA or DNA chain takes a few seconds, and there should be hundreds and thousands of such acts. In comparison with them, all purely enzymatic processes can be considered to be very fast.

The longest processes are the construction of the working apparatus of the cell: ribosomes, mitochondria, etc. The time required for this construction, in different biological organisms, is different: from hours to days.

In unicellular organisms, the time of construction is basically of the same order as the period of reproduction, i.e. lifetime. Thus, as soon as the cell apparatus is built and started working, the cell reproduces again (divides).

In multicellular organisms, the cell lifetime in a stable state can be much longer than the cell construction time. This is because in higher organisms, each cell lives not only for itself, but also performs certain functions for the whole organism. The processes of cell construction are the most inertial, because they are mainly associated with long delays in the body's response to external influences.

Thus, in any investigated time interval it is possible to allocate some main defining reactions and to construct the system of differential equations for them.

In the mathematical study of such systems of differential equations, we can get important information about biochemical processes that take place in cells.

However, it is often difficult or impossible to solve even simplified systems of differential equations in analytical form accurately. Therefore, it is often sufficient to know only the basic qualitative 
characteristics of the solutions. These characteristics are valuable when comparing the results of mathematical modeling of biochemical processes in biological systems with experimental ones.

Conclusions and prospects for further research. Mathematical modeling of biochemical processes rates in biological systems is performed in the article. The example of enzymatic reactions is considered and investigated.

A promising area of further research is mathematical analysis of qualitative characteristics of the solutions of systems of differential equations that describe biochemical processes rates in biological systems.

\section{Список бібліографічного опису}

1. .К. Робінзон (2015) Ферменти: принципи та біотехнологічне застосування. Essays Biochem., № 59, C. 1-41.

2. П.К. Агарвал (2006) Ферменти: інтегрований погляд на структуру, динаміку та функції. Microbial Cell Factories, т. 5, № 2. https://doi.org/10.1186/1475-2859-5-2.

3. Т. Палмер, Ф.Л. Боннер (2007) Ферменти: біохімія, біотехнологія, клінічна хімія. 2-ге вид., Woodhead Publishing.

4. Б. Демидович, В. Моденов (2008) Дифференциальные уравнения. 3-е изд., Санкт-Петербург: Лань.

5. Д.Г. Зілл (2017) Периий курс з диференціальних рівнянь з додатками для моделювання. 11-те вид., Сеngage Learning.

6. А. Стразерс, М. Поттер (2019) Диферениіальні рівняння: для науковиів та інженерів. 2-ге вид., Springer.

\section{References}

1. Robinson, P.K. (2015) Enzymes: principles and biotechnological applications. Essays Biochem., no. 59, P. 1-41.

2. Agarwal, P.K. (2006) Enzymes: an integrated view of structure, dynamics and function. Microbial Cell Factories, vol. 5 , no. 2. https://doi.org/10.1186/1475-2859-5-2.

3. Palmer, T. \& Bonner, P.L. (2007) Enzymes: biochemistry, biotechnology, clinical chemistry. 2nd ed., Woodhead Publishing.

4. Demidovich, B. \& Modenov, V. (2008) Differential Equations. 3rd ed., Saint Petersburg: Lan.

5. Zill, D.G. (2017) A first course in differential equations with modeling applications. 11th ed., Cengage Learning.

6. Struthers, A. \& Potter, M. (2019) Differential equations: for scientists and engineers. 2nd ed., Springer. 